\title{
A comparative study of marine zooplankton communities in the Tangier and M'Diq (Gibraltar strait) regions
}

\section{Étude comparative de la communauté zooplanctonique de la région de Tanger et M'Diq (détroit de Gibraltar)}

\author{
A. Zaafa(1), O. Ettahiri(2), A. Berraho(2), N. Elkhiati(1), L. Somoue ${ }^{(2)}$ \\ S. Zizah(2), M. Ramdani( ${ }^{(3)}$, M. Blaghen ${ }^{(1)}$, R. Flower ${ }^{(4)}$ \\ (1) Faculté des Sciences Ain Chock, Dép. Biologie, km 8 Route d’El Jadida, BP 5366, Casablanca, Morocco \\ zaafaamal@yahoo.fr \\ (2) Institut National de Recherche Halieutique, 2 rue de Tiznit, Casablanca 01, Morocco \\ (3) Institut Scientifique, BP 703, avenue Ibn Batouta, CP 10106, Rabat-Agdal, Morocco \\ (4) University College London, Pearson Building, Gower Street, London, WC1E 6BT, UK
}

\begin{abstract}
This comparative study of mesozooplankton communities in the Tangier (Atlantic) and M'Diq (Mediterranean) regions was carried out in March, May and December 2006 and in May, July and November 2007. In both sectors, the zooplankton is mainly dominated by copepods, which represent $93 \%$ in Tangier and $87 \%$ in M'Diq, with respectively 85 species in 24 families and 81 divided into 22 families. Spatio-temporal analysis of Copepod specific richness data revealed highest values occurring in both areas during December 2006 and November 2007 with 36 and 30 species respectively. During other seasons, specific richness did not generally exceed 25 species. However, irrespective of area, the composition of the Copepoda population was usually dominated by Paracalanus parvus and Oncaea venusta. In terms of total density, the Atlantic is greater than the Mediterranean sector with a maximum density of 1093 ind.m-3 and 796 ind.m-3, respectively, recorded in July and May, 2007. The Shannon diversity index was calculated and indicated that the Copepod community is more stable and balanced in the Tangier region compared to the M'Diq area, and in 2007 compared to 2006. Moreover, seasonal variation is more marked in the Atlantic than in the Mediterranean area and in both sectors, the autumn season is characterized by a low productivity but high specific diversity.
\end{abstract}

Key words - zooplankton composition, copepods, biological indexes, Tangier, M'Diq

Résumé - Cette étude comparative des communautés mésozooplanctoniques de la région de Tanger (Atlantique) et M'Diq (Méditerranée) a été réalisée en mars, mai et décembre 2006 et en mai, juillet et novembre 2007. Dans les deux secteurs, le peuplement zooplanctonique est dominé essentiellement par les copépodes qui représentent $93 \%$ à Tanger et $87 \%$ à M'Diq, avec respectivement, 85 espèces réparties en 24 familles et 81 réparties en 22 familles. L'analyse spatio-temporelle de la richesse spécifique a montré que le peuplement copépodique était plus riche en espèces dans les deux radiales étudiées en décembre 2006 et novembre 2007 avec respectivement 36 et 30 espèces. Durant les autres saisons, la richesse spécifique ne dépasse pas 25 espèces. Toutefois, indépendamment de la radiale étudiée, le peuplement des copépodes était généralement dominé par les espèces Paracalanus parvus et Oncaea venusta. Les plus fortes densités en copépodes ont été enregistrées au niveau de la radiale de Tanger (Atlantique) avec des valeurs maximales 
de 1093 ind. $\mathrm{m}^{-3}$ et 796 ind. $\mathrm{m}^{-3}$ enregistrées, respectivement, en juillet et mai 2007. L'analyse de la variabilité spatio-temporelle de la diversité spécifique a révélé que le peuplement copépodique était plus structuré et équilibré en 2007 qu'en 2006, en Atlantique qu'en Méditerranée. En outre, la variation saisonnière est plus marquée en Atlantique qu'en Méditerranée et en automne où les deux radiales ont été caractérisées par une faible productivité mais une grande diversité spécifique.

Mots clés - composition du zooplancton, copépodes, indices biologiques, Tanger, M'Diq

\section{INTRODUCTION}

The continental Moroccan Atlantic shelf has been the subject of several zooplankton studies since the 1950s. The first were carried out by Furnestin (1959), Giron (1963), Mazza (1967), Seguin (1973), Furnestin and Belfquih (1976). These studies were followed up by more recent work including Belfquih (1980), Boucher (1987), Chiahou and Ramdani (1997), Somoue (2004) and Somoue et al. (2005).

However, the zooplankton community of the two sides of the Gibraltar Strait did not benefit from this interest. The works carried out on these areas focused on the study of the hydrological and physico-chemical parameters (Thomsen, 1931; MeGill, 1965; Schink, 1967; Coste et al., 1969, Gentili, 1987; Minas et al., 1991; Minas and Minas, 1993; Bryden et al., 1994; Bray et al., 1995; Bethoux, 1999; Garcia Lafuente et al., 2000; Huertas et al., 2009). According to Harris et al. (2000), the zooplankton community is very sensitive and highly reactive to the environment variations. In many cases, a change of the structure of the zooplankton populations reflects a change in hydrological and climatic conditions. For this reason, many authors suggested using the zooplankton like an indicator of the global change (Fromentin \& Planque, 1996; Edwards et al., 2001; Beaugrand et al., 2000, 2002). In this context, our primary goal is to compare copepod population structure in two marine ecosystems, using various biological indexes. The second objective is to follow the spatiotemporal variation of the copepods community in both ecosystems to indicate biological exchanges between the Atlantic Ocean and the Mediterranean environments.

\section{MATERIAL AND METHODS}

\subsection{Studies areas and sampling}

Two sectors were investigated using a transect methodology: the first transect on the Atlantic coast was in the area of Tangier, and the second on the Mediterranean coast, in the area of M'Diq. On each transect, three stations were sampled. The mesozooplankton was sampled during the following periods: March, May and December 2006; May, July and November 2007 (Fig. 1).

The zooplankton samples were collected using a small size Bongo net with $145 \mu \mathrm{m}$ of mesh size. The net had a flowmeter for measurement of the filtered water volume. Sampling was carried out in a standard way: bottom to the surface, where the net is trailed horizontally for 3 minutes (at constant speed) and then hauled up vertically in 1 minute. Then it is towed at the 


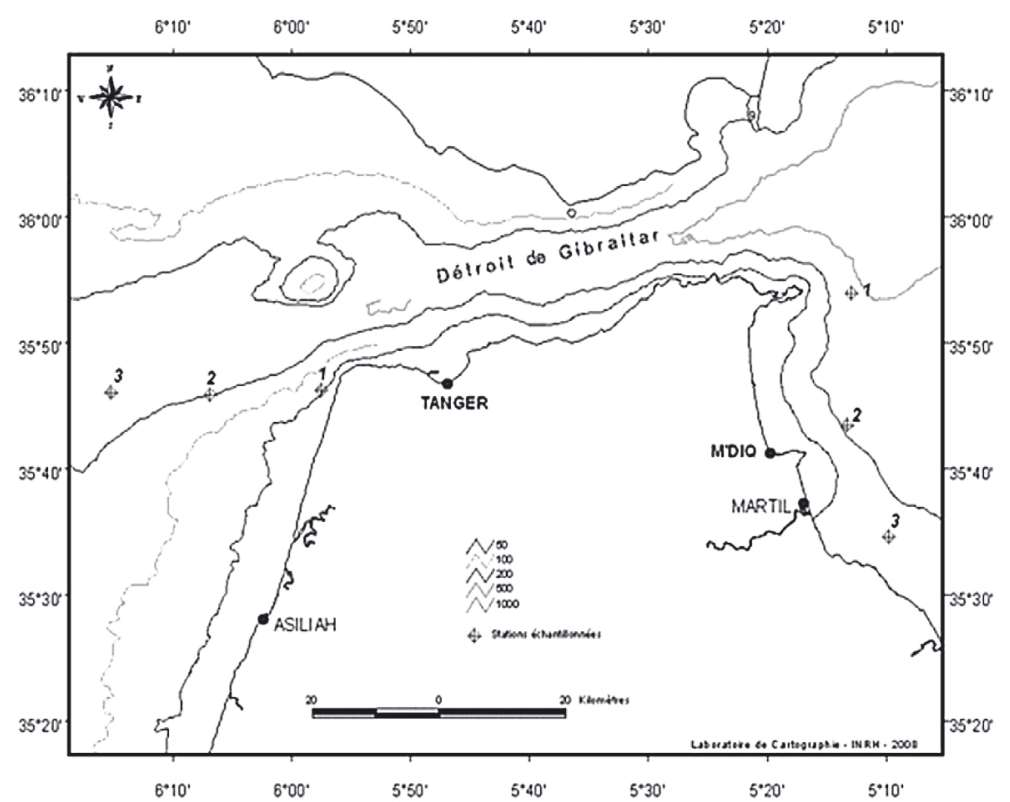

Fig. 1. Prospected areas and localisation of the sampled stations.

Fig. 1. Présentation du milieu et localisation des stations échantillonnées.

next depth at the same speed (varying between 2 and 3 knots) and again for three minutes. The samples were fixed with seawater formolized at $5 \%$. This sampling method was used by several authors including Ferreiro and Labarta (1984), Chesney \& AlonzoNoval (1989), Chiahou \& Ramdani (1996) and Somoue et al. (2005).

Identification and counting of zooplankton were carried out under a binocular microscope, after dividing the initial sample into fractions with the Motoda box (Motoda, 1959). Thus, we compiled a specific list for each sample using suitable keys for taxon determination (Rose, 1933; Tanaka, 1957; Tregouboff \& Rose 1957; Crisafi \& Mazza, 1966; Frost \& Fliminger, 1968; Bradford et al., 1983; Bradford-Grieve, 1994).

\subsection{Biological Indexes calculation}

After the harmonization of the count tables, data analysis was carried out following the calculation of several biological indexes, as follow:

- Total density (D) = number of individuals of different species of the copepods found in a sample/volume of filtered water.

- Abundance $(A)=$ (density of species I/total density) * 100 .

- The specific richness (S) = number of species present in a sample.

- The Shannon index H (Shannon \& Wiener, 1949) is a specific diversity mesure (Margalef, 1958 in Frontier, 1983).

$$
H=-\sum_{i=1}^{s}\left(P_{i} \times \log _{2} P_{i}\right)
$$


with $P_{i}$ : dominance of species $i$, and $P_{i}=n_{i} / N$

$n_{i}$ : the number of individuals of the species $i$ in the sample

$N$ : total number of individuals in the sample.

\subsection{Statistical analysis of data}

A cluster analysis of data, based on the "average linkage" was established using the software Statistica (Lance \& Williams, 1967; Legendre, 1984). The principle of this method is to give the same weight to all the objects in the calculation of the average association. For each cruise, the density of each species was averaged over the 3 prospected stations. The Copepoda list used for this analysis is limited to taxa of which the percentage abundance is higher than the threshold of $0.5 \%$ of the total of individuals collected per period (Dessier, 1983; Lam Hoai et al., 1985).

\section{RESULTS}

\subsection{Qualitative structure of zooplankton community}

\subsubsection{Copepods list}

In both sectors, the zooplankton community is dominated by copepods, which account for $93 \%$ in Tangier and $87 \%$ in M'Diq, with 85 and 81 listed species respectively. The majority of these species are cosmopolitan or with a large geographical distribution (Tab. I).

\subsubsection{Specific richness of copepods}

The spatio-temporal analysis of the specific richness of copepods in the Tangier area showed high richness in 2006 as well as in 2007. The maximum number of species was recorded in December 2006 with 33 taxa and in November 2007 with 36 taxa. These values were recorded respectively at the offshore and intermediate stations (Fig. 2).

In M'Diq, the space variation of the specific richness of copepods is less marked than the temporal one. The periods December 2006 and November 2007 are characterized by maximum numbers of species compared to the other periods (30 and 29 respectively). Except for the period December 2006, the intermediate station was richer in species during the various periods (Fig. 2).

The variance analysis (ANOVA 1) shows that the space variation (between stations and areas) and interannual variation, of the specific richness are non-significant. On the other hand, the variation between periods is highly significant $(P<0.01)$ in both regions.

\subsection{Quantitative variation of copepods}

In general, the total density of copepods is higher in 2007 compared to 2006 (Fig. 3), with a maximum on the Atlantic coastal station (1093 ind. $\mathrm{m}^{-3}$ in July 2007), and on the Mediterranean intermediate station (783 ind. $\mathrm{m}^{-3}$ in May 2007). In spite of strong space variability, the seasonal variability shown in both transect data sets is weaker but copepods 


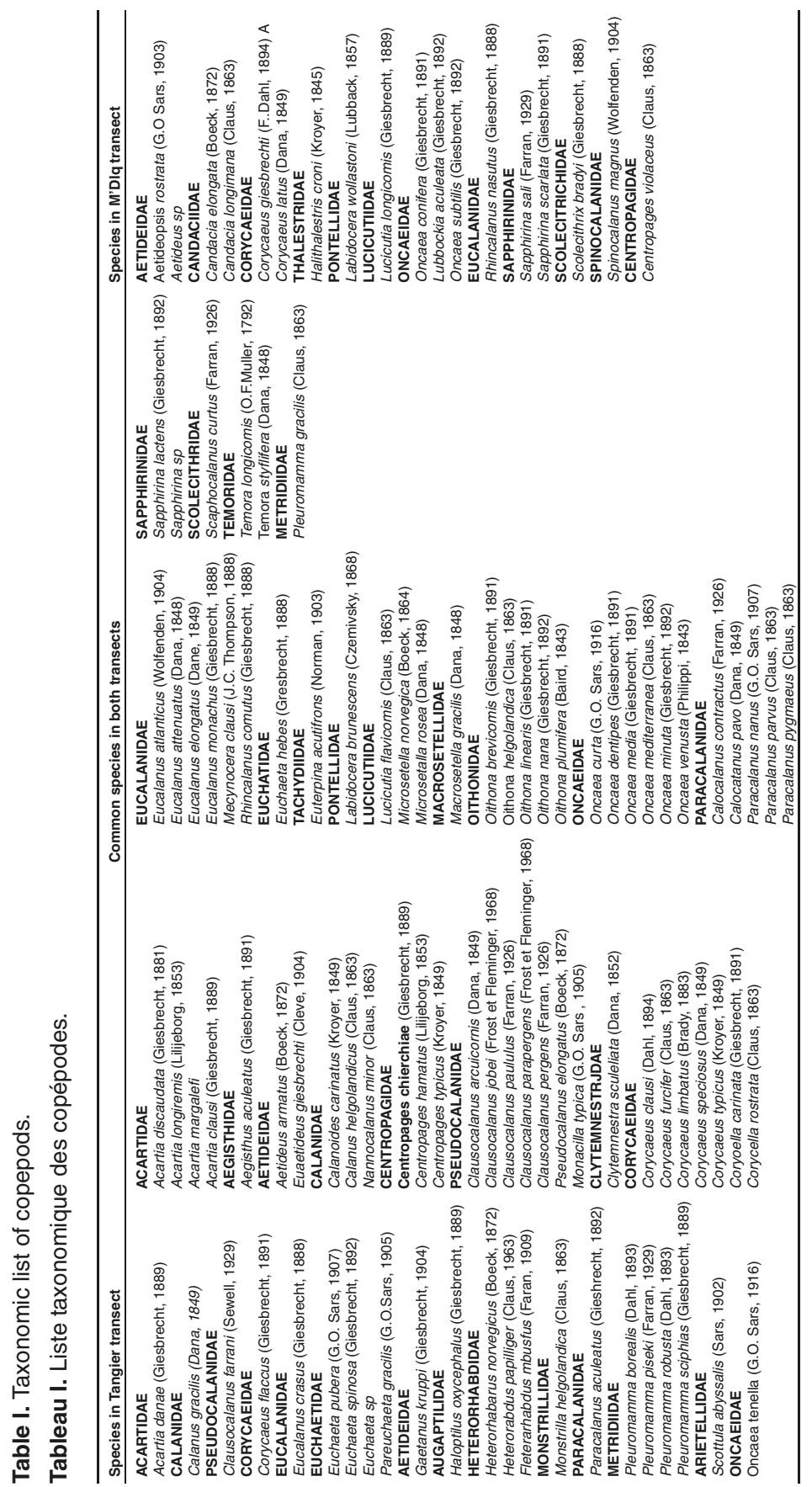



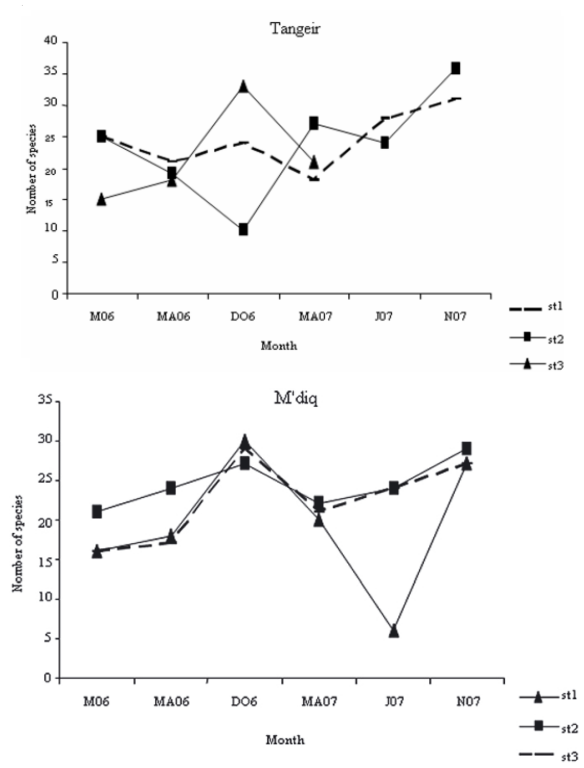

Fig. 2. Spacio-temporal variation of the species richness in Tangier and M'Diq. M06: March 2006; MA06: May 2006; D06: December 2006; MA07: May 2007; J07: July 2007; N07: November 2007 (st1, st2 and st3: sampling points in Fig. 1).

Fig. 2. Variation spatio-temporelle de la richesse spécifique à Tanger et M'Diq.

are less abundant in autumn (December 2006 and November 2007) compared to the summer (in Atlantic) or spring-summer (in the Mediterranean). In the latter period, the strongest densities of the copepods occurred. However, spatio-temporal variations are not significant between stations and periods (as tested by analysis variance ANOVA).

\subsection{Variation of the specific diversity}

The analysis of the spatio-temporal variability of specific diversity revealed that the copepod communities are

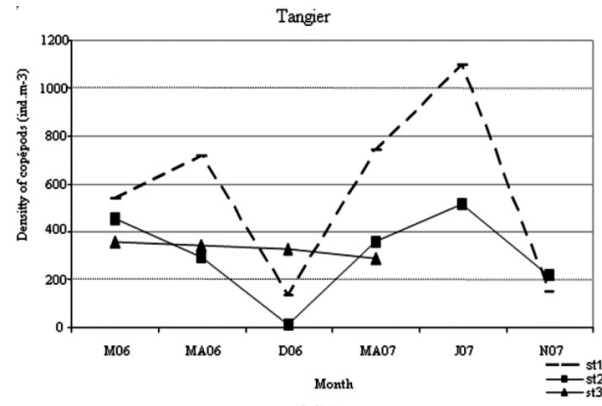

M'diq

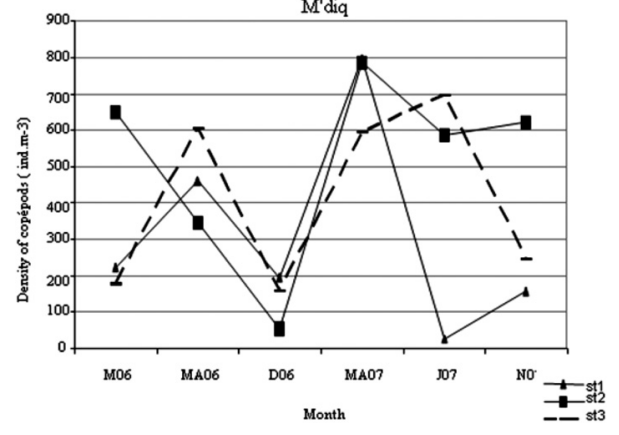

Fig. 3. Spatio-temporal variation in the total densities of copepods at the two areas.

Fig. 3. Variation spatio-temporelle de la densité totale des copépodes au niveau des deux radiales.

more structured and balanced in 2007 than in 2006 and in the Atlantic more than in the Mediterranean (Fig. 4). This situation corresponds with the autumn season, whereas the population is less structured during the other periods in both areas (Fig. 4) with an apparent space variation along the transect but not significant $(P<0.05)$. The interannual variation is significant for the Atlantic (with the threshold 0.05) whereas it is not significant in Mediterranean sector. 


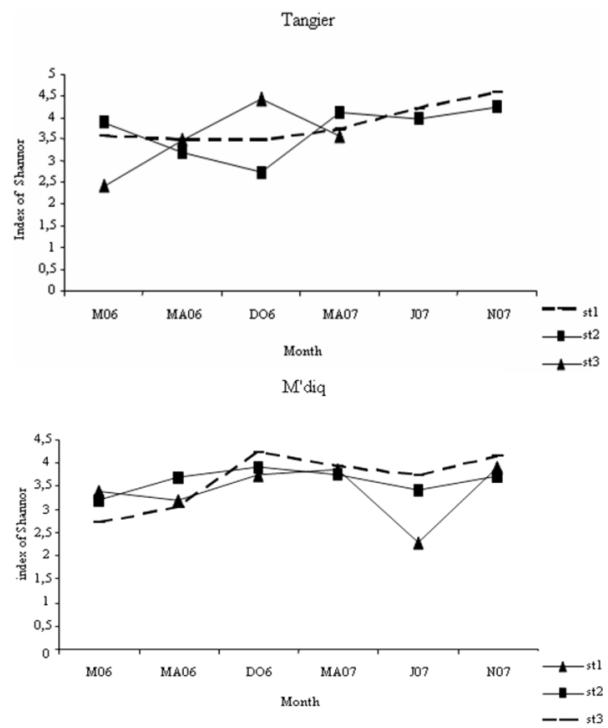

Fig. 4. Spatio-temporal variation of the Shannon index $\left(\mathrm{H}^{\prime}\right)$ in Tangier and M'Diq.

Fig. 4. Variation spatio-temporelle de l'indice de Shannon ( $\left.\mathrm{H}^{\prime}\right)$ à Tanger et M'Diq.

\subsection{Specific affinity of the copepods community}

\subsubsection{Atlantic transect (species)}

The hierarchical analysis carried out on the densities of the Copepods in various periods made it possible to distinguish between two independent groups of species at an Euclidean distance from 80 (Fig. 5A). The first grouping is represented by two subgroups:

SG1: composed mainly of Calanus helgolandicus, Oncaea venusta, Euchaeta hebes, Paracalanus pygmaeus and Nannocalanus minor. These taxa presented a strong contribution within the settlement of the Copepoda $(48.8 \%)$. The strong con-

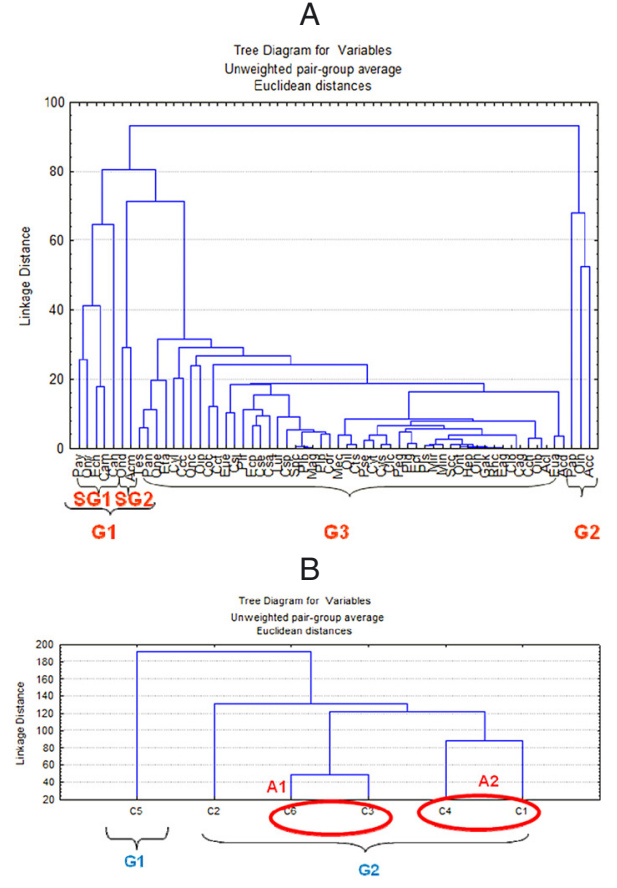

Fig. 5. Similarity between the different species of copepods (A) and the months (B) in Tangier. C1 is March 2006; C2 is May 2006; C3 is December 2006; C4 is May 2007; C5 is July 2007 and C6 is November 2007.

Fig. 5. Similarité entre les différentes espèces de copépodes $(A)$ et les mois $(B)$ à Tanger.

tribution of these cryophilic species was recorded in July 2007. SG2: represented by the two species; Acartia margalefi and Oncaea dentipes, with a cumulated abundance of $33 \%$, can be attached to the first grouping (July 2007) and corresponds to the period of May 2006.

The second grouping is dominated by Paracalanus parvus, Oithona helgolandica and Acartia clausi, with an average frequency abundance of $40.5 \%$. On the temporal level, this 
grouping corresponds to the periods of March 2006 and May 2007 characterized by the predominance of these thermophilous species.

The third grouping includes other less abundant species that are grouped by high affinities. Among the species characterizing this grouping there are rare species such as Paraeuchaeta gracilis, Lucicutia flavicornis and clausocalanoidae, which have similar percentage abundances.

\subsubsection{Atlantic transect (months)}

Two principal groupings were distinguished by hierarchical analysis (Fig. 5B). The first grouping (G1) corresponds to July 2007, when a characteristic copepod density peak (compared to the other periods) was recorded. The second group (G2) includes data from months characterized by average Copepod densities lower than those recorded in July 2007.

In this last group, May 2006 got singled out with an average density of 448 ind. $\mathrm{m}^{-3}$. The remaining parts are divided into two assemblies. The first assembly (A1) is represented by November 2007 and December 2006 when weak copepod densities were recorded. The second assembly (A2) gathers May 2007 and March 2006, characterized by copepodic densities ranging between 448 to 459 ind. $\mathrm{m}^{-3}$.

\subsubsection{Mediterranean transect (species)}

In M'Diq, three groupings of species were identified by the hierarchical analysis (Fig. 6A). The first grouping (G1)

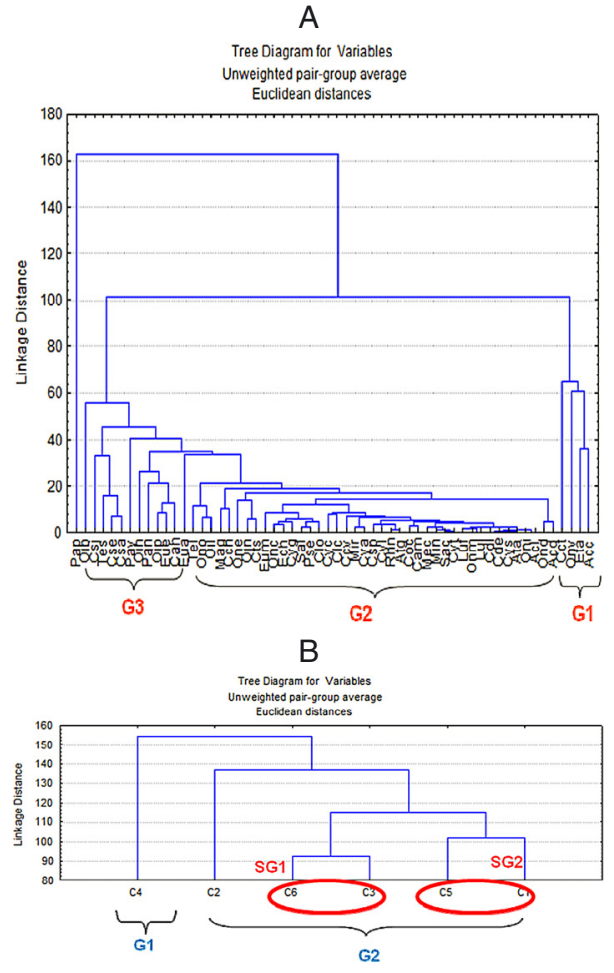

Fig. 6. Similarity between the different species of copepods $(A)$ and the months (B) in M'Diq. C1 is March 2006; C2 is May 2006; C3 is December 2006; C4 is May 2007; C5 is July 2007 and C6 is November 2007.

Fig. 6. Similarité entre les différentes espèces de copépodes $(A)$ et les mois $(B)$ à M'Diq.

is characterized by the predominance of Centropages typicus, Acartia clausi, Oncaea venusta and Euterpina acutifrons mainly in spring and summer. This grouping, is also characterized by high copepod densities, with a strong contribution of thermophilic species.

The second grouping (G2), composed of other species showing a weak contribution within the community of the Copepoda. The accumulated 
percentage of this species group was the highest in autumn (December 2006 $(29.4 \%)$ and November 2007 (26.7\%)).

The third grouping (G3), includes species characterized by a great affinity, with a high percentage of presence and variable percentage of abundance according to the months. However, the species Paracalanus parvus dominates the community of the copepods in various periods of the study.

\subsubsection{Mediterranean Transect (months)}

As in the case of the Atlantic, two groupings were identified (Fig. 6B). The first group corresponds to May 2007, when maximum copepodic densities were recorded. May 2006 is individualized from other months representing the second group, when the density in copepod did not exceed 468 ind. $\mathrm{m}^{-3}$. The second group is forked into two subgroups. The first under group includes December 2006 and November 2007 and represents the first assembly of the months characterized by low copepodic densities, whereas, the second assembly represented March 2006 and July 2007 when densities varied between 347 and 434 ind. $\mathrm{m}^{-3}$.

\section{DISCUSSION}

This study of the copepod communities present on both sides of Gibraltar Strait revealed a considerable similarity in species occurring in the two prospected areas. Thus, 85 species were counted in Tangier area and 81 in M'Diq area, including 63 species common to both areas. Youssara \& Gaudy (2001) showed that specific diversity is usually larger in the Mediterranean waters because of the addition of some rare species that are absent from Atlantic waters. Elsewhere, Giron (1963) attributes the faunistic richness of the sea of Alboran to its topography which is characterized by a low continental shelf and to its geographical location near Atlantic waters. These waters host neritic and pelagic species as well as species of Atlantic origin.

The spatio-temporal comparison of the total densities of the copepods in the two studied transects revealed stronger densities recorded in Tangier (1093 ind. $\mathrm{m}^{-3}$ ) compared to M'Diq where the maximum density is 796 ind. $\mathrm{m}^{-3}$. According to Rodriguez et al. (1994), the accumulation of sea surface water in both anticyclonic gyres of the Mediterranean basin creates a thicker layer of water that is poor in nutrients (oligotrophic water).

In Tanger area, the total density of copepods starts to increase in May (2006 and 2007) to reach its maximum in July 2007 (1093 ind. $\mathrm{m}^{-3}$ ), before decreasing in December (134 ind. $\mathrm{m}^{-3}$ ). This seasonal cycle of the zooplankton activity along the Moroccan coast is related to the upwelling cycle which develops in spring, is reinforced in summer, attenuates in autumn and decreases in winter (Furnestin, 1959; Thiriot, 1978; Belvèze, 1991; Orbi \& Nemmaoui, 1992). On the other hand, in the M'Diq region, this seasonal variation is not well marked, however, as in the Atlantic, low copepod densities characterized November 2007 and December 2006 (132 ind. $\mathrm{m}^{-3}$ and 340 ind $\mathrm{m}^{-3}$ respectively). A peak 
of copepod abundance was noted in May 2007 (724 ind. $\mathrm{m}^{-3}$ ). Thus, the zooplankton activity in M'Diq can be related to the seasonal cycle of the Mediterranean water mass which follows change of flow entering and outgoing through the Gibraltar Strait (Larnicol et al., 1995; Traon et al., 2007). Moreover, Fernandez de Puelles et al., (2003) showed a seasonal cycle related to an oscillation of the zooplankton abundance with maximum values recorded during the first six months of the year.

According to the temporal analysis of specific diversity, the copepod community is more stable and balanced in autumn (December 2006 and November 2007) compared to the other periods investigated in the two studied sectors. Indeed, during this period, high values of the Shannon index were generated by a large number of species which are generally rare and stenothermal in November 2007 or by cryophilic and stenothermal species in December 2006. In the other periods, relatively hotter, the Copepod population in the two areas is less structured and balanced. Chiahou \& Ramdani (1997) and Somoue et al. (2005) noted respectively in the northern zone (EL Jadida area) and south of the Moroccan Atlantic (between Boujdor Cape and White Cape), low copepod diversity during the hot summer season.

The coast-offshore variability of the various biological indexes is not very well marked in the two areas. However in Tangier, the strong copepod densities were recorded in the coastal stations during the whole periods, except for December 2006 and November 2007. This corroborates the re- sults from Bainbridge (1972), Touré \& Gningue (1991) and Somoue et al. (2005) which underline a coastal localization of high zooplankton densities for the Atlantic. In the Western Mediterranean, Fernandez de Puelles et al. (2003) revealed a reduction of the Copepod abundance from the coast to offshore.

Seasonal variability in specific richness was recorded in both areas. Indeed, the highest values were observed in December 2006 and November 2007 (the specific richness reached a maximum value of 46 in the Atlantic and 47 in the Mediterranean), in opposition to the other months when the number of species listed did not exceed 30 and 25 respectively.

Cluster analysis allowed us to distinguish two copepod populations based on the degree of affinity between species:

- A structured and balanced population with low densities and a high specific richness, observed in autumn (December 2006 and November 2007) in the two prospected transects.

- A poorly structured population with high densities and a low specific richness observed during summer in the Atlantic and spring in the Mediterranean. An intermediate situation, with average densities and specific richness was observed in spring (Atlantic) or in spring and summer (the Mediterranean).

This variability of the structure of the copepod population can be attributed to environmental conditions. Roy (1992) confirmed that the structure difference of the zooplankton communities between the hot and cold 
months is related to the hydrological conditions. In the Atlantic, the presence of unbalanced population in summer is due to the strong intensity of the upwelling in this season (Wooster et al., 1976; Binet, 1991). Indeed, this phenomenon supports the development of certain species to the profit of others, which explains the imbalance of the copepod community structure during the hot months which is characterized by a low specific diversity (Bainbridge, 1972; Boucher, 1982; Jacques \& Tréguer, 1986; Diouf, 1991). In the Mediterranean, Atlantic flow and the well known anticyclonic gyre system of strong intensity occupy all the southern Western zone (Gil, 1994) and probably account for the various structural differences observed in the Copepod communities within the Mediterranean transect.

Based on previous work, there are species endemic to the Atlantic or to the Mediterranean Sea, and others are common to both sectors, including Paracalanus parvus and Oncaea venusta occurring during all periods with high percentages of abundance. Several authors (Gaudy, 1962; Mazza, 1967; Razouls, 1974) reported that these species were observed in all seasons and in different areas. Other species are endemic to the Atlantic, such as Pleurommama xiphias and Pleurommama borealis located near the coast in Tangier compared to M'Diq where these taxa are absent. However, we could not identify a species characteristic of the Mediterranean sea probably because our sampling was limited to shallower layers waters. The species Mecynocera clausi, a good indicator of upwelling in Atlantic, can be considered characteristic of exchange be- tween both areas: it presents a high percentage of abundance in Tangier mainly near the coast and in M'Diq, the presence of this species is limited to stations located in the north, with low abundance. These stations are characterized by a strong influence of Atlantic waters.

Because of likely future changes in those environmental conditions that affect copepod communities, not the least in global warming, it is wise to maintain monitoring of these communities in this sensitive AtlanticMediterranean boarder region.

\section{REFERENCES}

Bainbridge V., 1972. The zooplankton of the gulf of Guinea. Bull. Mar. Ecol. 8 : 61-97.

Beaugrand G., Reid P.C., Ibañez F. \& Planque B., 2000; Biodiversity of North Atlantic and North Sea calanoid copepods. Mar. Ecol. Prog. Ser. 204 : 299303.

Beaugrand G., Reid P.C., Ibañez F., Lindley A. \& Edwards M., 2002. Reorganization of North Atlantic Marine Copepod Biodiversity and Climate. Science 296 (5573) : 1692-1694.

Belfquih M., 1980. Les copépodes du plateau atlanto-marocain. Un cycle annuel dans les zones d'upwelling. Thèse Doct. $3^{\mathrm{e}}$ cycle. Univ. Aix-Marseille I. $126 \mathrm{p}$.

Belvèze H., 1991. Influence des facteurs hydroclimatiques sur la pêcherie marocaine de petits pélagiques côtiers. In Pêcheries ouest-africaines. Ed. ORSTOM, pp. 209-233.

Bethoux J.P. \& Gentili B., 1999. Functioning of the Mediterranean Sea: past and present changes related to freshwater input and climate changes. Journal of Marine Systems 20 : 33-47.

Binet D., 1991. Dynamique du plancton dans les eaux côtières ouestafricaines : écosystèmes équilibré et 
déséquilibrés. In Pêcheries ouestafricaines. Ed. ORTOM, pp. 117-136.

Boucher J., 1982. Peuplement des copépodes des upwellings côtiers nord-ouest africains. II Maintien de la localisation spatiale. Oceanologica Acta 5(2) : 199-207.

Boucher J., 1987. Déterminisme et dynamique de la répartition spatiale des populations de copépodes des zones de résurgences côtières nord est atlantique et du front Liguro-Provencal. Thèse Doc. État. Univ. Paris VI, 325 p.

Bradford J.M., Haakonssen L. \& Jillett J.B., 1983. The marine fauna of New Zealand: pelagic calanoid copepods: families Euchaetidae, Phaennidae, Scolecithricidae, Diaixidae, and Tharybidae. Mem. N.Z. Oceanogr. Inst. $90: 1-150$.

Bradford-Grieve J.M., 1994. The marine faune of New zeland: Megacalanidae, Calanidae, Paracalanidae, Mecynoceridae, Eucalinidae, Spinocalanidae, Clausocalanidae. Mem. N. Z. Oceanogr. Inst. 102 : 1-160.

Bray N.A., Ochoa J. \& Kinder T.H., 1995. The role of the interface in exchange through the Strait of Gibraltar. Journal of Geophysical Research 100 : 1077510776.

Bryden H.L., Candela J. \& Kinder T.H., 1994. Exchange through the Strait of Gibraltar. Progress in Oceanography $33: 201-248$.

Chesney E.J. \& Alonso-Noval M., 1989. Coastal upwelling and ecology life history of sardines (Sardina pilchardus) a long the Galcian coast of Spain. Rapp. P.V., Reun. Cons. Int. Explor. Mer. 191 : 63-69.

Chiahou B. \& Ramdani M., 1996. Observations sur les variations de la densité et de la biomasse des copépodes pélagiques des côtes atlantiques marocaines (Région d'El Jadida). Marine Lire 6 (1-2) : 21-25.

Chiahou B. \& Ramdani M., 1997. Systématique et distribution saisonnière des copépodes pélagiques de la côte atlantique marocaine (région d'El
Jadida). J. Rech. Océanogr. 22 (3) : 75-80.

Coste B., Le Corre P. \& Minas H.J., 1987. Re-evaluation of the nutrient exchanges in the Strait of Gibraltar. Deep Sea Research 35 : 767-775.

Coste B., Minas H.J. \& Nival P., 1969. Distribution superficielle des taux de production organique primaire et des Silicoflagellés entre la Sardaigne et la Tunisie (fév. 1968). Téthys 1 (3) : 573580.

Crisafi P. \& Mazza J., 1966. Revisione del genere Sapphirina J.V. Thompson, 1829. Atti Soc. Pelorit. Sci. Fis. Mat. Nat. 12 (3-4) : 561-618.

Dessier A., 1983. Variabilité spatiale et saisonnière des peuplements épiplanctoniques des copépodes du Pacifique tropical Sud et équatorial (Est-Pacifique). Oceanol. Acta 6 (1) : 80-103.

Diouf P.S., 1991. Le zooplancton au Sénégal : écosystèmes équilibrés et déséquilibrés. Pêcheries ouest africaines Ed. ORSTOM, pp. 103-116.

Edwards M., Reid P.C. \& Planque B. 2001. Long-term and regional variability of phytoplankton biomass in the Northeast Atlantic (1960-1995). ICES Journal of Marine Science 58 (1): 3949.

Fernandez de Puelles M., Pinot J.M. \& Valencia J., 2003. Seasonal and interannual variability of zooplankton community in waters off Mallorca island (Balearic sea, Western Mediterranean): 1994-1999. Inst. Espa. Oceano. Cent de Balears. Oceanologica Acta 26 : 673-686.

Ferreiro M.J. \& Labarta U., 1984. Spawning areas and seasons of three clupeid species (Sardina pilchardus, Spratus spratus and Engraulis encrasicolus) in the Ria of Vigo (Galcian coasts, NW Spain). Cybium 8 (3) : 79-96.

Fromentin J.M. \& Planque B., 1996. Calanus and environment in the eastern North Atlantic. II. Influence of the North Atlantic Oscillation on $C$. finmarchicus ans $C$. helgolandicus. 
Marine Ecology Progress Series 134 : 111-118.

Frontier S. (Ed.), 1983. Choix et contraintes de l'échantillonnage écologique. In Stratégies d'échantillonnage en écologie. Les Presses de l'Univ. de Laval, 3 : 62.

Frost B.W. \& Fleminger A., 1968. A revision of the genus Clausocalanus (Copepoda: Calanoida) with remarks on distributional patterns in diagnostic characters. Bull. Scripps Instn Oceanogr., Tech. Ser. $12:$ 1-235.

Furnestin J., 1959. Hydrologie du Maroc Atlantique. Rev. Trav. Inst. Pêches Marit. 23 (1) : 5-77.

Furnestin M.L. \& Belfquih M., 1976. Les copépodes du plateau continental marocain et du détroit canarien. II- Les espèces au cours d'un cycle annuel dans les zones d'upwelling. Cons. Int. Explor. Mer 9 : 1-18.

Garcia Lafuente J., Vargas J.M., Plaza F., Sarhan T., Candela J. \& Basheck B., 2000. Tide at the eastern section of the Strait of Gibraltar. Journal of Geophysical Research 105 (C6) : 14197-14213.

Gaudy R., 1962. Biologie des copépodes pélagiques du Golfe de Marseille. Recueil des travaux de la station marine d'Endoume, Vol. 27, pp. 93-184.

Gil J., 1994. Circulacion geostrofica e hidrografia del mar de Alboran en la campana ictio Alboran 0792. Inf. Téc. Inst. Esp. Oceanogr. 146 : 9-26.

Giron F., 1963. Copépodes de la mer d'Alboran (Compagne du Président "Théodore-Tessier" juin 1957). Rev. Trav. Inst. Pêches Marit. 27 (4) : 355402.

Harris R., Wiebe P., Lenz J., Skjoldal HR. \& Huntley M., 2000. ICES. Zooplankton methodology manual, Academic Press, San Diego, $684 \mathrm{p}$.

Huertas I.E., Rios A.F., Garcia-Lafuente J., Makaoui A., Rodriguez-Galvez S., Sanchez-Roman A., Orbi A., Ruiz J. \& Rérez F.F., 2009. Anthropogenic and natural $\mathrm{CO}_{2}$ exchange through the Strait of Gibraltar. Biogeoscience 6 : 647-662.
Jacques G. \& Tréguer P., 1986. Les écosystèmes pélagiques marins. Masson, Paris, New York, Barcelona, Milan, $243 \mathrm{p}$.

Lam Hoai T., Amanieu A. \& Lassere G., 1985. Communautés du zooplancton superficiel des trois sites différemment éloignés de l'entrée des eaux marines dans l'étang de thau. Cah. Biol. Mar. $X X V I$ : 445-467.

Lance G.N. \& Williams W.T., 1967. I. Comput. J. 2 : 98-103.

Larnicol G., Le Traon P.Y., Ayoub N. \& De Mey P., 1995. Mean sea level and surface circulation variability of the Mediterranean Sea from 2 years of TOPEX/POSEIDON altimetry. Journal of Geophysical Research 100 (C12) : 25163-25177.

Legendre L., 1984. Towards dynamic biological oceanography and limnology. Can. J. Fish. Aquat. Sci. 4 : 2-19.

Mazza J., 1967. Les copépodes pélagiques en Méditerranée occidentale (Développement post-larvaire, biologie, écologie). Thèse Doct. État. Univ. Aix Marseille I, $494 \mathrm{p}$.

MeGill D.A., 1965. The relative supplies of phosphate, nitrate and silicate in the Mediterranean Sea.Comm. int. Explor. Sci. Mer Médit., Rapp et P.V. 18 (3) : 737-744.

Minas H.J. \& Minas M., 1993. Influence du Detroit de Gibraltar sur la biogéochimie de la Méditerranée et du proche Atlantique. Annales de L'Institut Oceanographique Paris 69 : 203-214.

Minas H., Coste J.B., Le Corre P., Minas M. \& Raimbault P., 1991. Biological and geochimical signatures associated with the water circulation through the straits of Gibraltar and in the western Alboran Sea. J. Geophys. Res. 96 (C5) : 87558771.

Motoda S., 1959. Devices of simple plankton apparatus. Memoirs. Faculty of Fisheries. Hokkaido University 7, pp. 73-94.

Orbi A. \& Nemmaoui M., 1992. Fluctuations des vents et variabilité de l'upwelling le long de la côte atlantique marocaine. Trav. et Doc. $\mathrm{N}^{\circ} 75$ ISTPM. 
Pielou E.C., 1975. Ecological diversity. Wiley-Interscience, New-York.

Razouls C. \& Thiriot. A., 1974. Données quantitatives du mésoplancton en Méditerranée occidentale (saisons hivernales 1966-1970). Vie et Milieu 23 (2B) : 209-241.

Rodriguez V., Blanco J.M., Echevarria F., Rodriguez J., Jimenez-Gomez F. \& Bautista B., 1994. Nutrients, fitoplancton bacterias y material particulado del mar de Alboran, en julio de 1992. Inf. Téc. Inst. Esp. Oceanogr. 146 : 53-77.

Rose M., 1933. Copépodes pélagiques. Faune de France 26. Edit. P. Lechevalier, Paris, $374 \mathrm{p}$.

Roy C., 1992. Réponses des stocks de poissons pélagiques à la dynamique des upwellings en Afrique de l'ouest : Analyse et modélisation. Ed. ORSTOM. Collection Études et Thèses, Paris, pp. 5-146.

Schink D.R., 1967. Budget for dissolved silica in the Mediterranean Sea. Geochimica Cosmochimica Acta 31 : 987-999.

Seguin G., 1973. Cycles comparés du zooplancton dans l'ouest africain et la Méditerranée sud-occidentale. Étude systématique, quantitative et écologique. Thèse Doct. État. Univ. Lille, $168 \mathrm{p}$.

Shannon C. \& Wiener E., 1949. The Mathematical theory of communication. Urbana Illinois Press, $117 \mathrm{p}$.

Somoue L., 2004. Structure des communautés planctoniques de l'écosystème pélagique de l'atlantique sud marocain entre Cap Boujdor et Cap Blanc $\left(26^{\circ} 30^{\prime}-21^{\circ} N\right)$. Thèse Doct. Nationale, Fac. Sc. Ain chock, Univ Hassan II, $211 \mathrm{p}$.
Somoue L., El khiati N., Ramdani M., Lam Hoi T., Berraho A. \& Do Chi T., 2005. Abundance and structure of copepod communities along the Atlantic coast of southern Morocco. Acta Adriat. 46 (1) : 63-76.

Tanaka O., 1957. The pelagic copepods of the Izu region. Middle Japan. Systematic Account III. Family Aetideidae (Part. I). Publs. Seto. Mar. Boil. Lab. 6 : 31-68.

Thiriot A., 1978. Zooplankton communities in the west African Upwelling area. In Upwelling ecosystems. R. Boje \& M. Tomczak, Eds., Springer-Verlag, pp. 32-61.

Thomsen H., 1931. Nitrate and phosphate contents of Mediterranean water. Rep. Dan. Oceanogr. Exped. 1908-1910. M Edit. Adj. Seas, Miscellaneous Papers 3 (6), pp. 1-14.

Touré D. \& Gningue I.D., 1991. Variation spatio-temporelle de la biomasse phytoplanctonique sur le plateau continental sénégalais : écosystème équilibré et déséquilibré. Pêcherie ouest-africaine. Ed. ORSTOM, Paris, pp. 90-102.

Traon P.Y., Larnicol G., Ayoub N. \& De Mey P., 2007. Variabilité océanique en Méditerranée. http://www.aviso. oceanobs.com/fr/kiosque/newsletter/ newsletter04.

Tregouboff G. \& Rose M., 1957. Manuel de planctonologie méditerranéenne. Tomes I et II. CNRS Paris 1, pp. 1-181.

Wooster W.S., Bakun A. \& Mc Lain D.R., 1976. The seasonal upwelling cycle along the eastern boundary of the north Atlantic. J. Mar. Res. 34 : 131-141.

Youssara F. \& Gaudy R., 2001. Variations of zooplankton in the frontal area of the Alboran sea (Mediterranean sea) in winter 1997. Oceanol. Acta 24 (4) : 361376. 